\title{
PERANCANGAN GEDUNG CONVENTION HALL DENGAN PENDEKATAN ARSITEKTUR KONTEKSTUAL DI KABUPATEN PURWAKARTA
}

\author{
Novita $^{l}$, Karya Widyawati ${ }^{2}$, Marselly DwiPutri ${ }^{3}$ \\ ${ }^{1}$ Universitas Indraprasta PGRI, Program Studi Arsitektur \\ novitav091@gmail.com \\ ${ }^{2}$ Universitas Indraprasta PGRI, Program Studi Arsitektur \\ karya.widyawati@unindra.ac.id \\ ${ }^{3}$ Universitas Indraprasta PGRI, Program Studi Arsitektur \\ marselly_dwiputri@yahoo.com
}

\begin{abstract}
Purpose design of convention hall building with a contextual architectural approach in Purwakarta district is as a facility for meeting buildings that are sufficient in terms of capacity and a representative building as facilities that can accommodate seminars, exhibitions, art shows/performances and information exchange that will be making Purwakarta district increasingly in the field of development. The design method chosen in the construction of the convention hall in Purwakarta district is a contextual method, namely a design method that considers and provides responses to various characters around it (environment) in response to the environmental context including local architectural styles, physical environmental structures, climate, and culture public (ikhwanuddin, 2004:158).
\end{abstract}

Key Words: Design, Convention Hall, Meeting hall, Contextual Architecture

\begin{abstract}
Abstrak : Tujuan Perancangan Gedung Convention Hall dengan pendekatan arsitektur kontekstual di Kabupaten Purwakarta yaitu sebagai wadah fasilitas gedung-gedung pertemuan yang mencukupi dari segi kapasitas serta gedung yang representatif sebagai fasilitas yang dapat mewadahi kegiatankegiatan seminar, pameran, pertunjukan/pagelaran seni dan pertukaran informasi yang akan menjadikan Kabupaten Purwakarta semakin meningkat dalam bidang pembangunan. Metode perancangan yang dipilih dalam pembangunan Convention Hall di Kabupaten Purwakarta adalah metode kontekstual yaitu metoda desain yang mempertimbangkan dan memberikan tanggapan terhadap berbagai karakter di sekitarnya (lingkungan) tanggapan terhadap konteks lingkungan meliputi, gaya arsitektur lokal, struktur lingkungan fisik, iklim dan budaya (culture) masyarakat (ikhwanuddin, 2004:158).
\end{abstract}

Kata Kunci : perancangan, Convention Hall, gedung pertemuan, Arsitektur Kontekstual

\section{PENDAHULUAN}

Kabupaten Purwakarta merupakan salah satu kabupaten di Provinsi Jawa Barat yang memiliki banyak sarana pariwisata, kebudayaan, industri serta area komersil. Purwakarta juga memiliki potensi dari segi lokasi yang cukup strategis dan potensi pasar yang mampu diperluas untuk mengembangkan suatu usaha. Gagasan mengenai keberadaan suatu convention hall bermula dari kebutuhan untuk memfasilitasi pertemuan-pertemuan berskala nasional yang sering diadakan di Kabupaten Purwakarta sekaligus menyikapi Surat Edaran Mentri Kebudayaan dan Pariwisata Nomor : PW.202/2/5/MKP/2007 tentang penugasan Gubernur seluruh Indonesia untuk mensukseskan MICE. Permasalahan di Kabupaten Purwakarta terhadap penyebaran ilmu pengetahuan sebagai akibat dari adanya potensi yang belum diberdayakan secara optimal serta adanya beberapa kelemahan-kelemahan yang belum teratasi dengan baik. Banyaknya investor yang masuk dan industri yang akan dibangun menjadi potensi meningkatnya kegiatan pertemuan serta pertukaran informasi melalui kegiatan seminar, rapat ataupun pameran. Kebutuhan akan tempat konvensi diperkuat dengan adanya isu strategis pemerintah untuk membangun fasilitas konvensi dalam rangka menanggapi Rencana Pembangunan Jangka Panjang Daerah (RPJDP) Kabupaten Purwakarta tahun 2005-2025.

Pembangunan Convention hall di Kabupaten Purwakarta merupakan pembangunan gedung konvensi yang fungsimya diarahkan 
sebagai pusat kegiatan pertemuan regional, diskusi, seminar, pameran sampai pagelaran seni. Perencanaan pembangunan ini berlokasi di Kawasan komersil yang berhubungan langsung dengan fasilitas komersil lainnya.

Penerapan arsitektur kontekstual dianggap cocok karena sesuai dengan Peraturan Daerah Kabupaten Purwakarta nomor 9 tahun 2006 Paragraf 5 tentang Arsitektur Bangunan Pasal 13 ayat 1 yang berbunyi Bentuk Bangunan gedung harus dirancang dengan memperhatikan bentuk dan karakteristik yang ada disekitarnya. Dan merupakan program Bupati Purwakarta yang ingin melestarikan budaya sunda di Purwakarta maka tema yang dipilih adalah Kontekstualisme Arsitektur Sunda di Purwakarta.

\section{METODOLOGI}

Metode yang digunakan dalam penelitian ini menggunakan metode kualitatif. Metode ini berupa penelitian yang menghasilkan data deskriptif berupa kata tertulis/lisan dari orangorang atau perilaku yang dapat diamati dengan menggunakan pendekatan deduktif.

Metode ini dalam pendekatan perenanaan adalah sebagai acuan untuk menyusun landasan perencanaan Convention Hall, diantaranya ;

a. Pengumpulan data primer, meliputi ;

1) Rencana Tata Ruang dan Wilayah (RTRW) Kabupaten Purwakarta tahun 2011-2031 mengenai wilayah kecamatan Purwakarta sebagai zona komersil.

2) Studi literatur tentang pengembangan kawasan komersil di Kabupaten Purwakarta.

3) Rencana Pemerintah dalam pengembangan bangunan gedung konvensi dalam rencana pembangunan jangka Panjang daerah.

b. Pengumpulan data sekunder, antara lain;

1) Studi banding atau presedent arsitektur mengenai perencanaan proyek convention sejenis.

2) Pengamatan langsung permasalahan di lapangan mengenai permasalahan yang terjadi saat ini di Kabupaten Purwakarta.

3) Pemanfaatan maksimal potensi di sekitar Convention Hall.

4) Pengamatan tentang perkembangan penyebaran informasi saat ini di Kabupaten Purwakarta.
5) Menganalisa perilaku kegiatan masyarakat setempat dalam penyebaran informasi atau kegiatan konvensi.

\section{HASIL DAN PEMBAHASAN \\ Pengertian dan tujuan Convention Hall}

Menurut Fred Lawson 1981 Convention didefinisikan sebagai pertemuan oleh orang orang untuk sebuah tujuan atau untuk bertukar pikiran, berupa pendapat dan informasi dari sesuatu perhatian atau permasalahan bersama dari sebuah kelompok. Convention pada umumnya tentang pemberian informasi yang dikemas dalam sebuah topik dan biasanya terdapat pameran atau eksibisi di dalamnya. (Lawson, 1981:2). Sedangkan hall adalah istilah dari Bahasa Inggris yang artinya adalah ruang, sedangkan kata ruang memiliki arti kelas atau tempat yang luas untuk melakukan sesuatu.

Kesimpulan dari pengertian-pengertian di atas, dapat ditarik kesimpulan bahwa convention hall merupakan sebuah besaran ruang atau ruangan tertutup yang mampu menampung seluruh peserta dengan sejumlah aktivitas yang berkaitan dengan konvensi. Pada dasarnya, setiap bangunan tertutup harus mampu mengakomodasi seluruh kebutuhan okupan selama berada di dalam gedung sehingga aktivitas dapat berjalan sesuai dengan tujuannya.

Fungsi Convention Hall menurut Fred Lawson (1981) ialah:

a) Sebagai media komunikasi sebuah kelompok untuk membahas permasalahan, mempresentasikan karya/produk, untuk bertukar pikiran dan saling tukar menukar informasi.

b) Wisuda dan upacara penghargaan lainnya

c) Pertunjukan musik

d) Pernikahan/perkawinan dan ulang tahun (perorangan maupun golongan)

e) Pameran

Tujuan Convention Hall menurut Fred Lawson (1981) yaitu:

a) Memecahkan masalah dalam organisasi dalam bentuk pertemuan agar saling berbagi pendapat.

b) Memberi wadah kegiatan komunikasi untuk setiap kelompok atau pelaku yang membutuhkannya.

c) Tempat untuk berbagi ilmu dalam kegiatan seminar ataupun workshop. 
d) Meningkatkan kualitas pariwisata di suatu daerah dengan menarik atau mengundang banyak pengunjung dari luar kota sehingga juga sebagai ajang promosi kota setempat.

\section{Konteks Urban}

Berdasarkan RTRW Kabupaten Purwakarta Tahun 2011-2031 kecamatan Purwakarta merupakan bagian wilayah dari Kabupaten Purwakarta yang memiliki potensi dari segi lokasi yang cukup strategis dan potensi pasar yang mampu diperluas untuk mengembangkan usahanya, Kabupaten Purwakarta cukup banyak dilirik oleh para investor maupun pengembang sebagai lokasi yang cukup potensial untuk mengembangkan usahanya. Banyaknya investor yang masuk dan industri yang akan dibangun menjadi potensi meningkatnya kegiatan pertemuan serta pertukaran informasi melalui kegiatan seminar, rapat ataupun pameran. Fasilitas gedung konvesi merupakan salah satu fasilitas umum yang sangat berpotensi besar untuk dikembangkan di Kabupaten Purwakarta.

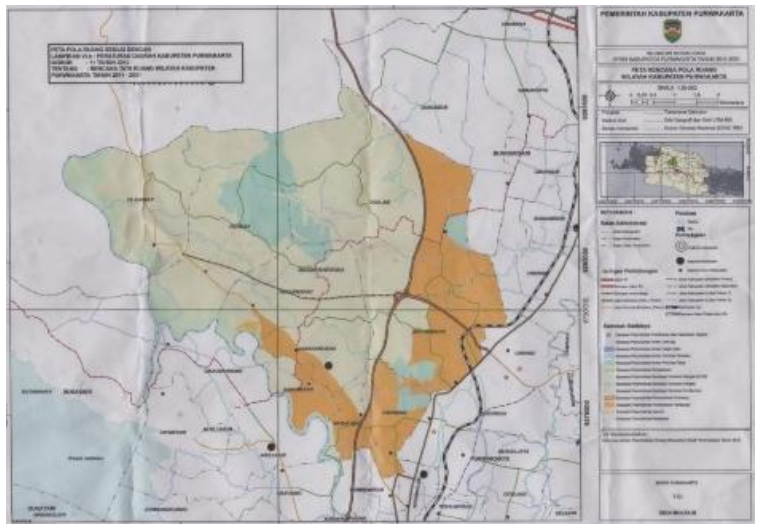

Gambar 1. Peta RTRW Kabupaten Purwakarta, Jawa Barat

\section{Analisis Tapak}

Wilayah ini berada di titik koordinat $107^{0} 26^{\prime} 41.96$ " Bujur Timur 6033'06.52" Lintang Selatan. Ketinggian tanah 0-2 \%. Pada site topografi cenderung rata dengan curah hujan 0$182 \mathrm{~mm}$.

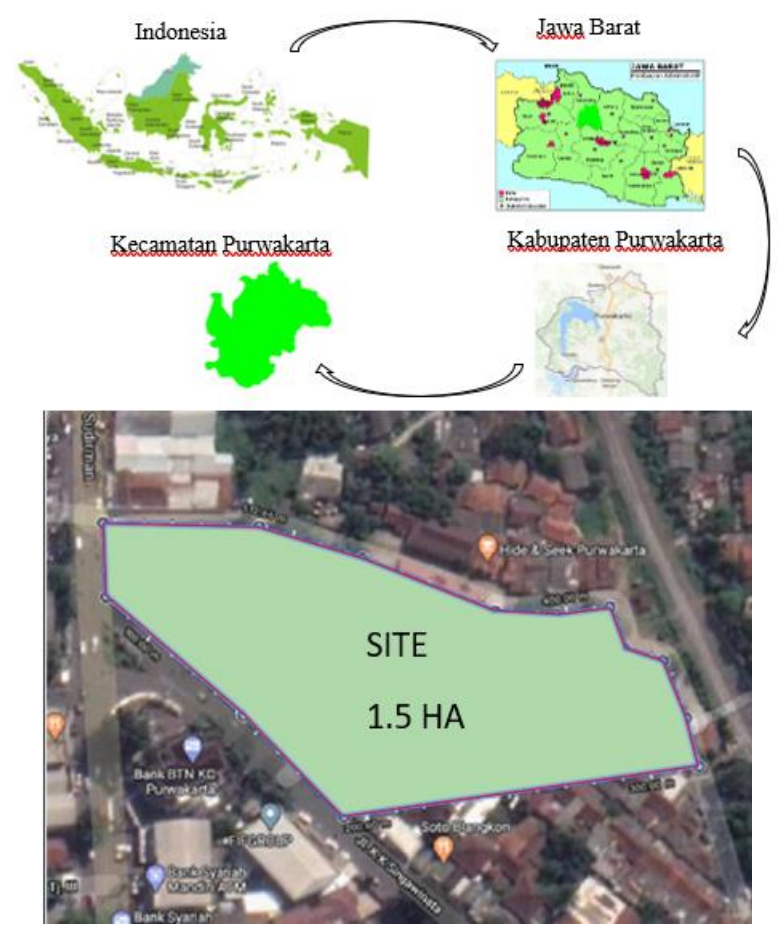

Gambar 2. Lokasi site

Lokasi site berada di Kawasan Komersil yang terintegrasi oleh perkantoran, permukiman penduduk dan jalan utama, Jl. Jenderal Sudirman, Kecamatan Purwakarta Jawa Barat. Dan lokasi site dekat dengan stasiun Purwakarta.

Dengan batas - batas wilayah adalah:

Batas Utara : Pertokoan

Batas Timur : Permukiman warga

Batas Selatan : Pertokoan

Batas Barat : Jl. K.K. Singawinata dan Jl. Jendral Sudirman

Menurut Peraturan daerah Kabupaten Purwakarta tentang RTRW dan peraturan zonasi ditetapkkan ;

Luas Lahan $\quad: 15.000 \mathrm{~m}^{2}$

KDB $\quad: 60 \%$

KLB $: 2$

Lahan Terbangun : Luas Lahan $\mathrm{x}$ KDB

$: 15.000 \times 60 \%$

KLB : KLB / Luas Lantai Maksima $: 2 \times 15.000$

$: 30.000 \mathrm{~m}^{2}$

Jumlah Lantai KLB / Luas Lantai Maksimal : $30.000 / 9.000$

: 3,3 lantai (3 lantai) 


\section{Metode Perancangan Desain}

Metode Pendekatan yang di gunakan untuk perancangan Convention Hall ini menggunakan pendekatan Arsitektur Kontekstual yaitu merupakan metode desain yang mempertimbangkan dan memberikan tanggapan terhadap berbagai karakter di sekitarnya (lingkungan) tanggapan terhadap konteks lingkungan meliputi, gaya arsitektur lokal, struktur lingkungan fisik, iklim dan budaya (culture) masyarakat (ikhwanuddin, 2004:158).

Bentuk konsep bangunan di transformasikan dari motif atau corak yang menjadi ciri khas setempat dengan proses tipologi yaitu klasifikasi dalam arsitektur berdasar ruang-bentuk, fungsi dan langgam. Melalui proses transformasi bentuk yang berasal dari bentuk Gapura Indung Karahayuan yaitu gapura yang menjadi ciri khas di kabupaten Purwakarta yang keberadaanya sudah menjadi suatu bagian pada setiap bangunan perkantoran pemerintah, sekolah dan gang kecil diseluruh wilayah Kabupaten Purwakarta. gapura ini juga terdapat di gerbang masuk Kabupaten Purwakarta. Berikut ini merupakan proses diagram konsep tapak bangunan Convention Hall.

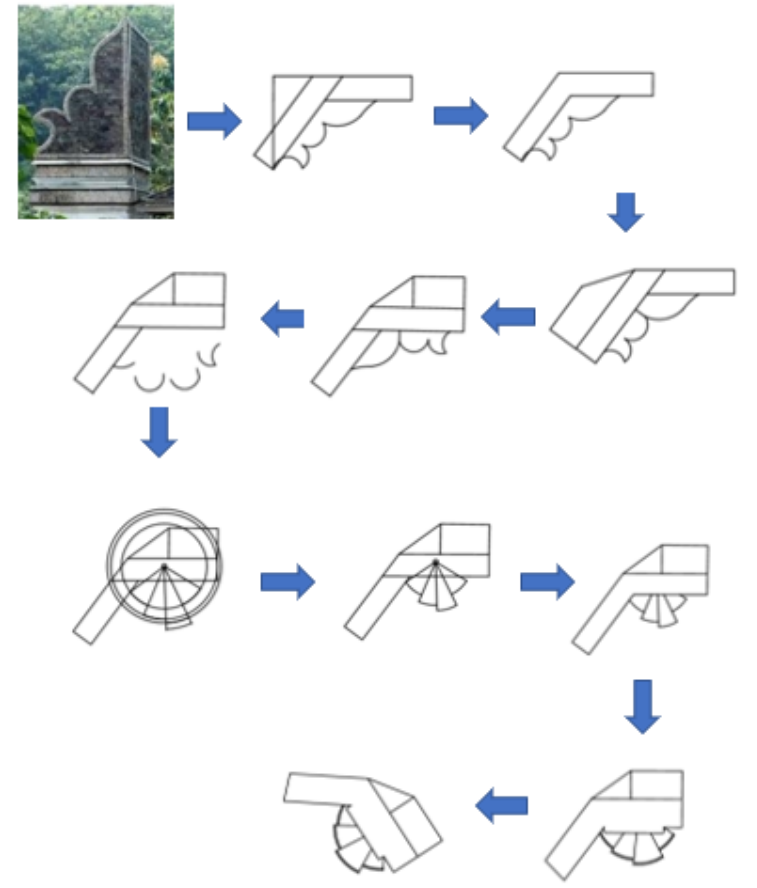

\section{Analisa Pencapaian}

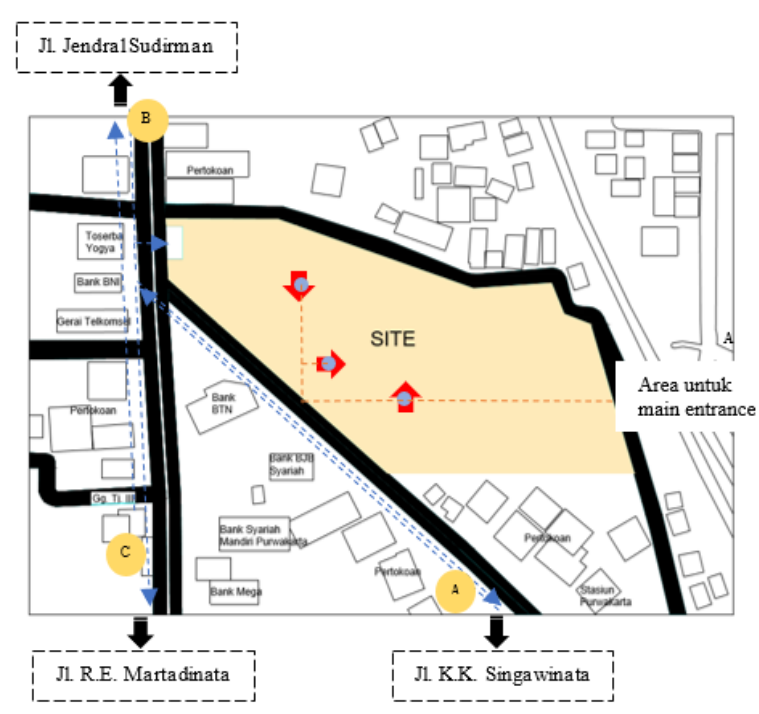

Gambar 4. Pencapaian

Pencapaian dari site eksisting dapat di tempuh melalui ;

- Dari sebelah utara yaitu dari Jalan Jenderal Sudirman

- Dari arah selatan yaitu melalui Jalan K.K Singawinata

- Dan arah barat yaitu melalui Jalan R.E Martadinata

\section{Analisa Angin/penghawaan alami}
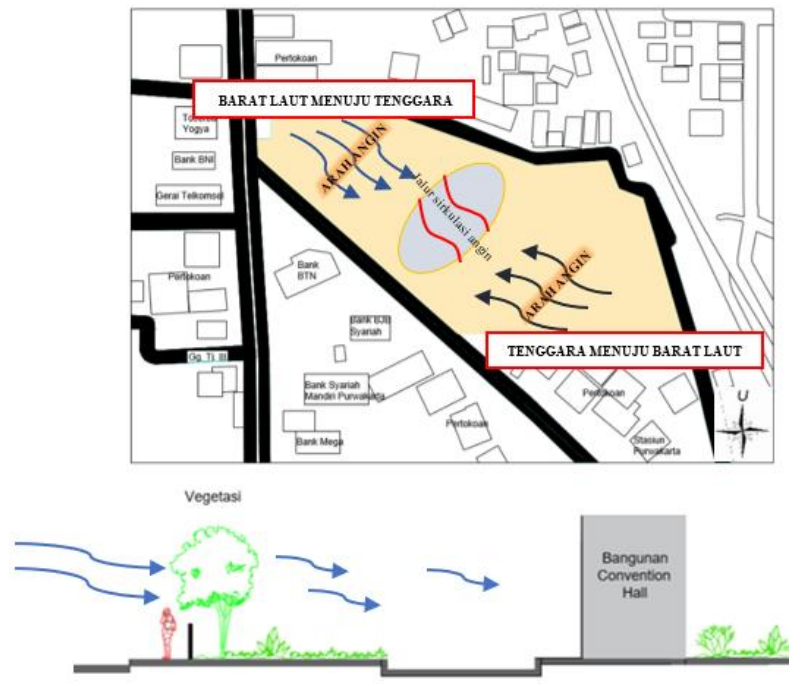

Gambar 5. Arah angin

Gambar 3. Gubahan Massa

Sumber: Analisa pribadi, 2020 


\section{Zonasi}
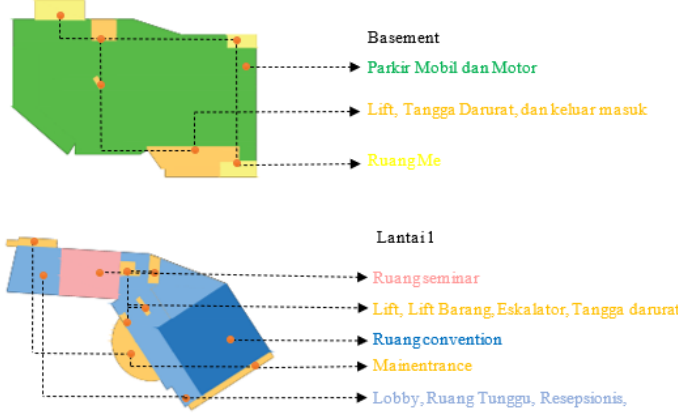

dan Food Court

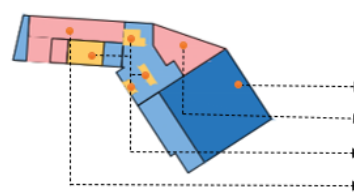

Gambar 6. Zonasi

\section{Desain}

1) Block Plan

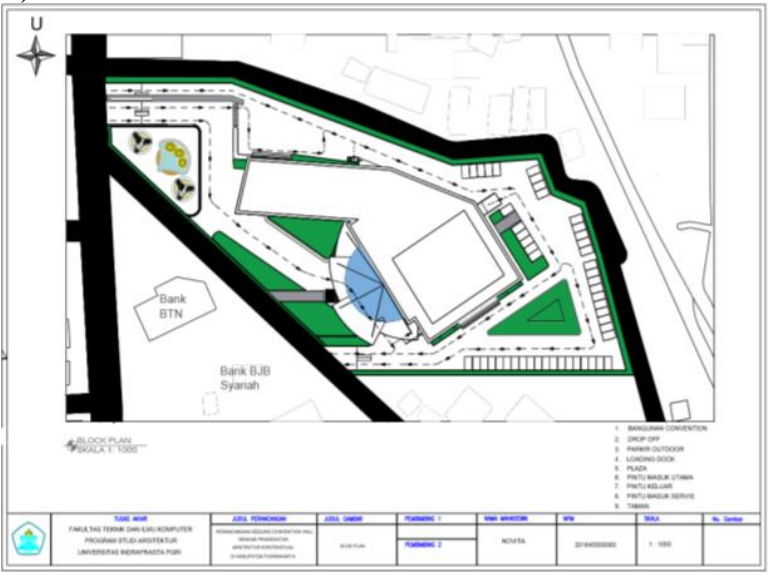

Gambar 7. Site Plan

\section{2) Site Plan}

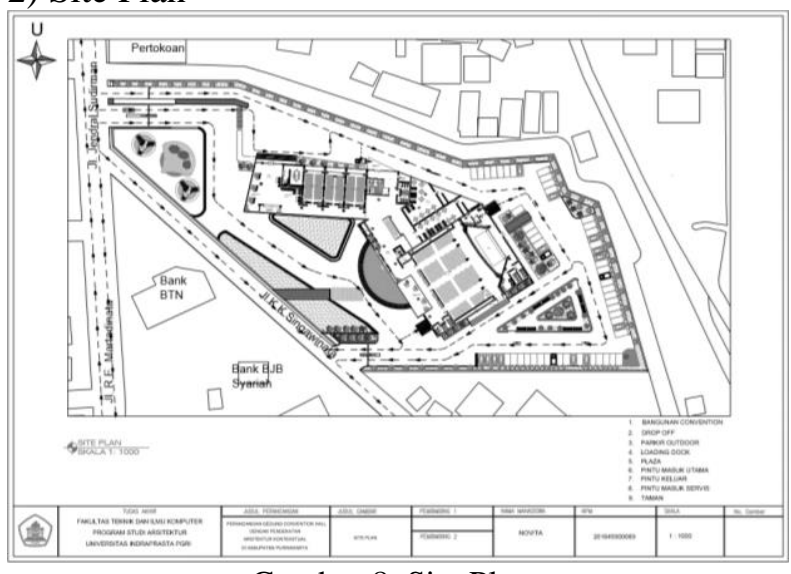

3) Denah

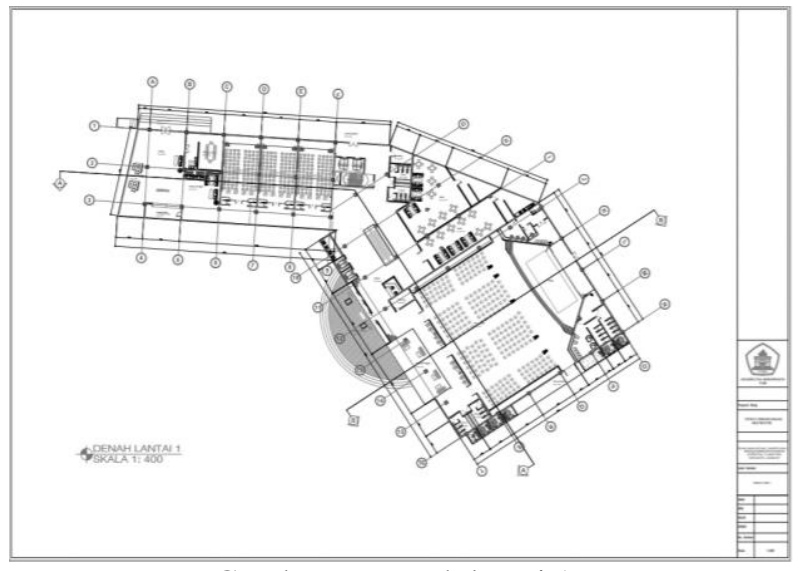

Gambar 9. Denah lantai 1

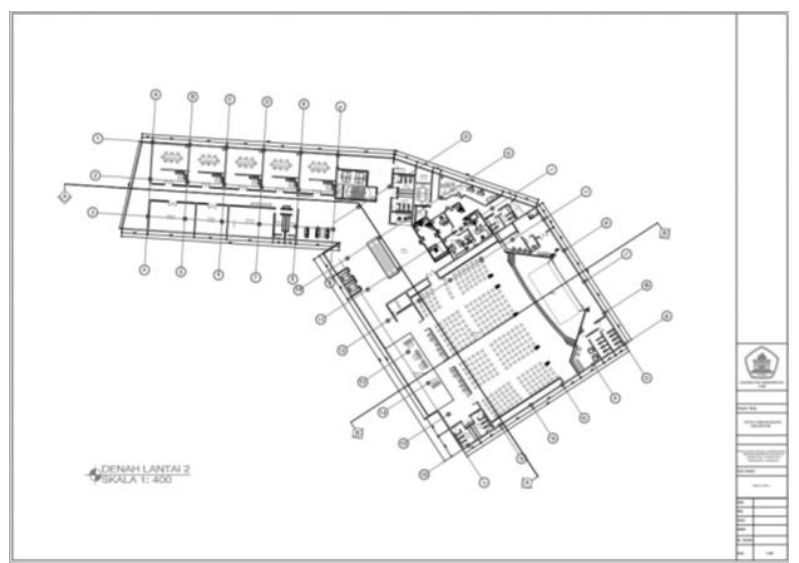

Gambar 10. Denah lantai 2

4) Perspektif
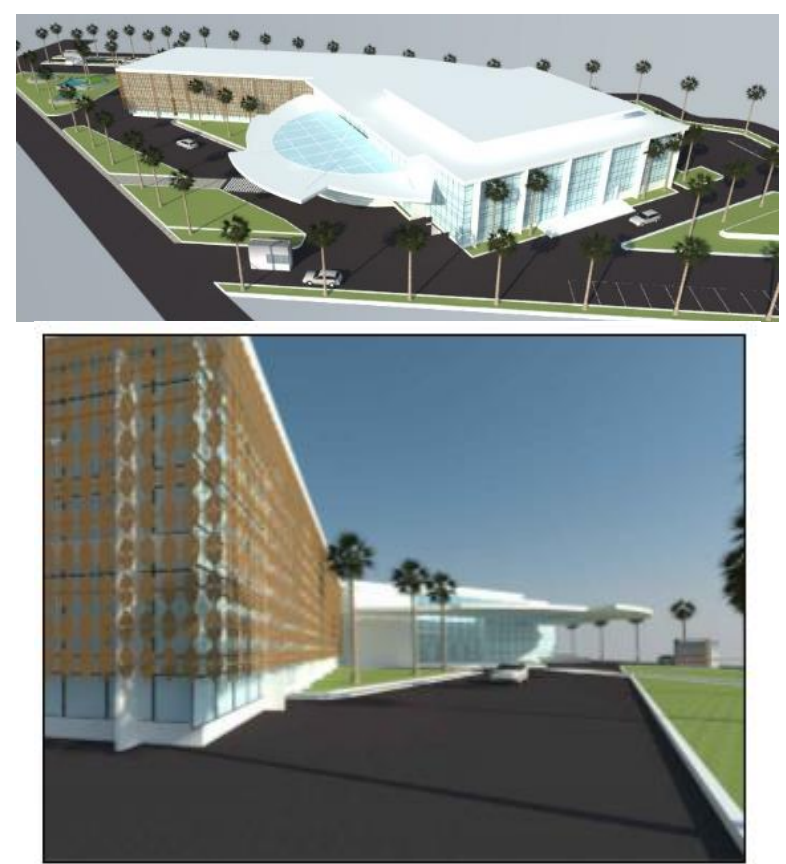

Gambar 11. Perspektif 
5) Fasad dan Interior bangunan

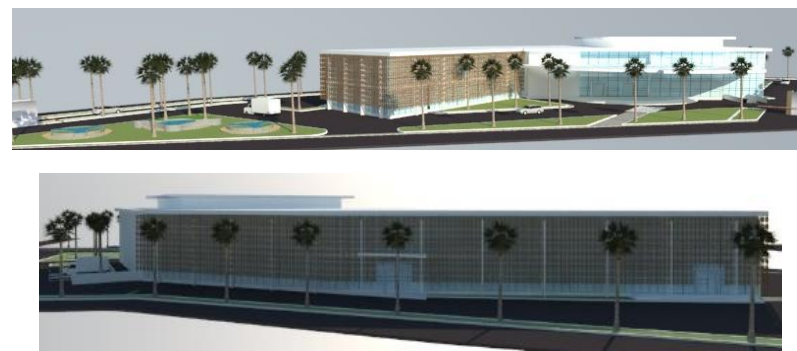

Gambar 12. Fasad Bangunan
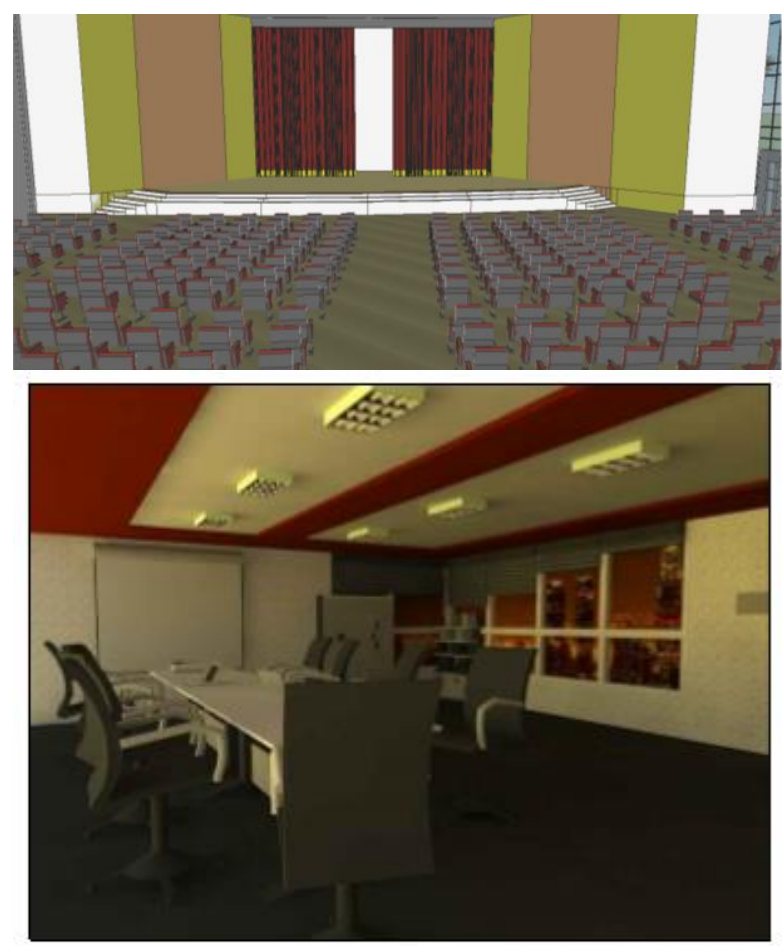

Gambar 13. Interior

\section{PENUTUP \\ Simpulan}

Perancangan Convention Hall di Kabupaten Purwakarta dengan pendekatan arsitektur Kontekstual memiliki konsep yang bertujuan untuk mengembangkan fasilitas gedung konvensi sesuai standar dan dapat memberi kenyamanan, keamanan, dan kemudahan kepada masyarakat pengguna gedung konvensi.

\section{Saran}

Convention Hall untuk memberikan karakter yang kuat pada bangunan, perlu diadakan kajian mendalam terhadap potensi budaya juga keadaan lingkungan sekitar agar memberikan rasa nyaman terhadap pengguna bangunan. Perancangan
Convention Hall ini harus bisa mengatasi permasalahan yang ada pada tapak yang sudah di tentukan dan terdata.

\section{DAFTAR PUSTAKA}

Ching, Francis DK. 1985.Arsitektur: Bentuk, Ruang, dan Tatanan. Terjemahan. Jakarta: Erlangga.

Lawson, Fred. 1981. Conference, Convention and Exhibition Facilities. London: the Architectural Press.

Rencana Pembangunan Jangka Panjang Daerah (RPJDP) Kabupaten Purwakarta tahun 2005-2025.

Sutanto, Handoko. 2015. Prinsip-Prinsip Akustik Dalam Arsitektur. Jakarta: Kanisius.

Mustofa. 2019. Perancangan Stasiun Tanah Abang Dengan Metode Transit Oriented Development (TOD). Jurnal Lakar Arsitektur, Vol 02 (2) : 85 - 92 